\title{
Церковно-приходское обучение на территории православного прихода Вознесения Господня в Клейниках
}

\section{Adrian Kuprianowicz}

\author{
badacz niezależny, Polska \\ adriankuprianowicz@wp.pl
}

\begin{abstract}
A. Kuprianowicz, Orthodox-parochial education in the orthodox parish of the Ascension of Jesus Christ in Klejniki, Elpis, 20 2018: 57-64.
A. Kuprianowicz, Szkolnictwo cerkiewno-parafialne na terenie parafii prawosławnej pod wezwaniem Wniebowstapienia Pańskiego w Klejnikach, Elpis, 20 2018: 57-64.
\end{abstract}

\begin{abstract}
The Orthodox-parochial education system in the Klejniki parish had a rich history. At those times, the educational system was above all for the benefit of the poor community. The Orthodox-parochial education in Klejniki was not on a particularly high level. In October 1884, 8 grammar schools were established within the parish of Klejniki. Towards the end of the 19th century, the parish had already 11 schools teaching 240 children. In the year 1893/1894, 6 boys from the Klejniki parish finished their education in the Orthodox teacher training college in Trześcianka-Stawek. A significant role in the organisation of the intellectual life and the development of Orthodox education in the countryside was played by the priest Jan Chlebcewicz. He was the founder of the Florenti Pawlenkow library and reading room.

The financial burden, problems of accommodation for the teachers, an insufficient number of well qualified teachers, the poverty of the parents of the children attending the schools had a negative impact on the general state of the education in the Klejniki parish. The Orthodox education and school system contributed substantially to the eradication of illiteracy among the rural population. The First World War and the mass exodus into Russia were the immediate causes for the collapse of the library and reading room as well as all the schools in the parish of Klejniki.
\end{abstract}

\begin{abstract}
Streszczenie: Szkolnictwo cerkiewno-parafialne w klejnickiej parafii posiadało bogatą tradycję. Szkolnictwo owe służyło przede wszystkim biednemu społeczeństwu tamtego czasu. Oświata cerkiewno-parafialna w Klejnikach nie stała na specjalnie wysokim poziomie. W październiku 1884 roku na terenie klejnickiej parafii powstało 8 szkół gramot. Pod koniec XIX wieku, w parafii istniało już 11 szkół, w których naukę pobierało 240 dzieci. W 1893/1894 roku 6 chłopców z klejnickiej parafii ukończyło edukację w cerkiewno-nauczycielskiej szkole w Trześciance-Stawku. Znaczącą rolę w organizowaniu inteligenckiego życia oraz rozwojowi cerkiewnej oświaty we wsi odegrał ks. Jan Chlebcewicz. Był on założycielem biblioteki-czytelni im. Florentego Pawlenkowa.

Ciężar finansowy, problemy z zakwaterowaniem dla nauczycieli, niewystarczająca liczba dobrze przygotowanej nauczycielskiej kadry, biedota rodziców dzieci uczęszczających do szkoły miały negatywny wpływ na ogólny stan oświaty w klejnickiej parafii. Oświata oraz cerkiewne szkolnictwo w znacznym stopniu przyczyniły się do likwidacji analfabetyzmu wśród wiejskiej ludności. Pierwsza wojna światowa oraz bieżeństwo były bezpośrednimi przyczynami, które przyczyniły się do upadku biblioteki-czytelni oraz wszystkich szkół w klejnickiej parafii.
\end{abstract}

\begin{abstract}
Аннотация: Церковно-приходское обучение в Клейникском приходе имело богатые традиции и служило, прежде всего, делу просвещения беднейшего населения того времени. Уровень обучения в церковно-приходских школах был не специально высокий. В октябре 1884 года на территории Клейникского прихода были созданы 8 школ грамоты. В конце XIX века в приходе имелось уже 11 школ, в которых училось 240 детей. В 1893/1894 г. г. шесть мальчиков из Клейникского прихода окончили церковно-учительскую школу в Трестянке-Ставке. Существенную роль в повышении уровня интеллигентности жизни и развитии просвещения в селе играл священник Иоанн Хлебцевич. Именно он учредил библиотеку-читальню им. Флорентия Федоровича Павленкова.

Финансовые трудности, проблемы с организацией проживания учителей, недостаточные кадры хорошо подготовленных учителей, бедность родителей детей, посещающих школы-все это негативно сказывалось на общем уровне просвещения в Клейникском приходе. Просвещение и церковное обучение в значительной степени помогло в борьбе с неграмотностью среди сельских жителей. Первая мировая война и беженство стали причиной расформирования библиотек-читален и всех школ в Клейникском приходе.
\end{abstract}

Keywords: Orthodox-parochial education, grammar schools, library, reading room, Klejniki parish

Słowa kluczowe: szkolnictwo cerkiewno-parafialne, szkoły gramoty, biblioteka, czytelnia, parafia klejnicka

Ключевые слова: церковно-приходское обучение, школы грамоты, библиотека, читальня, Клейникский приход

Уровень знаний о церковно-приходском обучении в Клейникском православном приходе очень убогий. Православное просвещение в упомянутом приходе не было еще предметом детального анализа. Также не была написана какая-либо конкретная работа, хотя бы в общих чертах затрагивающая церковное обучение в Клейникском приходе. Тематикой церковного обучения занимались как польские, так зарубежные исследова- 
тели. К их числу, несомненно, можно отнести, в частности, К. Харламповича ${ }^{1}$, И. Крыпякэвыча ${ }^{2}$, С. Миропольского ${ }^{3}$, А. Ваньчуру ${ }^{4}$, А. Мироновича ${ }^{5}$, И. Матус ${ }^{6}$. Краткие упоминания на тему обсуждаемой проблематики можно также встретить в работе Л. Беньковского 7 В том числе детальная картина обучения в Польском Королевстве показана также в работах Я. Волчука, К. Познаньского ${ }^{8}$.

Восточная Церковь в Речи Посполитой создала в период перед разделом три типа школ, а именно: братские школы, монастырские школы и церковные школы. В период разделов на Подлесье развилось православное обучение различных ступеней. История официального церковно-приходского образования в Гродненской губернии охватывает период 1884-19159 г. г. Развитие церковно-приходского обучения на территории Клейникского прихода в то время очень точно описывают сохранившиеся Гродненские Епархиальные Ведомости и Литовские Епархиальные Ведомоcmu. Наиболее популярными школами, которые создавались, были школь грамотыл. Учительские кадры состояли из выпускников народных школ или лиц,

\footnotetext{
К. Харлампович, Западно-русские православные школь ХVI и начала XVII в., Казань 1898.

И. Крипякевич, 3 історії галицького шкільництвва XVI-XIII cm., Рідна шккла 1933, нр 2.

С. Миропольский, Очеркъ исторіи церковно-приходской школь оть перваго ея возникновенія на Руси до настоящаго времени, Санкт-Петербург 1985, вып. III; С. Миропольский, Очеркъ исторіu церковно-приходской школь отъ перваго ея возникновенія на Руси до настоящаго времени. Отъ основанія школь при св. Владимірг до монгольскаго ига.-Школь и образованіе въ эпоху монгольскаго ига.Образованіе и школь на Руси въ XV-XVII въках, Санкт-Петербург 1910, изд. II.

4 A. Wańczura, Szkolnictwo w Starej Rusi, Lwów 1932.

A. Mironowicz, Szkolnictwo prawosławne na ziemiach białoruskich w XVI-XVII wieku, [w:] Białoruskie Zeszyty Historyczne, [dalej: BZH], Białystok 1994, nr 2, s. 20-34; A. Mironowicz, Prawosławne szkolnictwo teologiczne na terenie Rzeczypospolitej [dalej: Prawosławne szkolnictwo teologiczne...], [w:] Od Kijowa do Rzymu. Z dziejów stosunków Rzeczypospolitej ze Stolica Apostolska i Ukraina, red. M. R. Drozdowski, W. Walczak, K. Wiszowata-Walczak, Białystok 2012, s. 863-880; A. Mironowicz, Orthodox Education in Poland, [w:] Elpis, Białystok 2016, s. 27-35.
}

I. Matus, Szkolnictwo cerkiewno-parafialne $w$ powiecie bielskim w latach 1884-1914 na tle sytuacji oświatowej $w$ diecezji grodzieńskiej, Białystok 2006; I. Matus, Szkolnictwo cerkiewno-parafialne w powiecie bielskim pod koniec XIX wieku i na poczatku XX wieku, Białystok 1994, BZH, nr 2, s. 48-64; I. Matus, W Puchłach, Stawku, Trześciance, Białystok 2000; I. Matus, W Drohiczynie, Jałówce, Potoce i Różanymstoku, Białystok 2001.

L. Bieńkowski, Organizacja Kościoła wschodniego w Polsce, [w:] Kościół w Polsce, red. J. Kłoczowski, t. II, Kraków 1969.

8 См.: J. Wołczuk, Rosja i Rosjanie w szkołach Królestwa Polskiego 1833-1862. Szkice do obrazu, Wrocław 2005; K. Poznański, Oświata i szkolnictwo w Królestwie Polskim 1831-1869. Lata zmagań i nadziei. Przebudowa systemu szkolnictwa $i$ wychowania $w$ Królestwie Polskim w latach 1831-1839, Warszawa 2001, t. I; K. Poznański, Oświata i szkolnictwo w Królestwie Polskim 1831-1869. Lata zmagań i nadziei. Szkoły rzemieślniczo-niedzielne, Warszawa 2001, t. II; K. Poznański, Oświata i szkolnictwo $w$ Królestwie Polskim 1831-1869. Lata zmagań i nadziei. Polityka oświatowa caratu w latach 1834-1861, Warszawa 2004, t. III.

I. Matus, Kursy nauczycielskie. Z historii oświaty cerkiewno-parafialnej $w$ diecezji grodzieńskiej 1900-1915, [у:] Культура Гродзенскага рэгіёну: праблемы развічия ва ўмовах поліэтнічнага сумежжа. Зборнік навуковых праи, Гродна 2001, с. 116. прошедших военную службу. Часто в таких образовательных учреждениях должность учителя получали крестьяне, научившиеся читать и писать. Уровень обучения в таких школах был очень низкий. Чаще всего эти школы имели нестабильный и временный характер. В результате школьной реформы и реорганизации обучения, имевшего место с XIX в., униатская приходская школа в Клейниках была переименована в российское Приходское училище ${ }^{10}$. При отсутствии доверия российских властей полонизированное униатское духовенство не допускалось на работу в ново открывающиеся образовательные учреждения ${ }^{11}$. И только в 1891 г. были приняты правила функционирования школ грамоты и они были переименованы в элементарные школы, которые должны были учреждаться в городах и селах. Больше всего в Литовской епархии их было открыто в Гродненской губернии, где первое место занимал Бельский повет.

Более широкое образовательное значение для народных школ грамоты имели одно-и двухклассные школы, в которых значительно больше внимания уделялось религиозному воспитанию детей по сравнению с другими предметами, с иным-принципиально-учительским составом (на практике, особенно в одноклассных школах, учителями все еще были дети крестьян и отставные солдаты) и школьным надзором. В этих школах были введены такие дополнительные предметы, как гимнастика, гигиена, ботаника, садоводство, пчеловодство, лечение лекарственными травами, арифметика, пение, игра на скрипке и строевая подготовка. В программе этих школ появились также профессиональные предметы: рисование, рукоделие, гимнастика и аграрные работы, дополненные общей подготовкой: педагогикой, арифметикой, дидактикой, психологией, русским языком, методикой обучения и историей. Продолжал обязывать основной религиозный канон: катехизис, теология, Закон Божий, церковное песнопение, история Церкви и т. п. ${ }^{12}$.

В 1884/1885 г. г. на территории Клейникского прихода были учреждены 8 школ грамоты. Они функционировали в селах: Гуковиче, Кожино, Ступники, Козлики, Городчино, Льахи, Яново, Градочно (польск. Hukowicze, Kożyno, Stupniki, Koźliki, Gorodczyno, Lachy, Janowo, Gradoczno) ${ }^{13}$. Роль инспектора этих школ в Клейникском приходе ${ }^{14}$ исполнял Флор Соснов-

10 I. Matus, Szkolnictwo cerkiewno-parafialne w powiecie bielskim w latach 1884-1914 na tle sytuacji oświatowej $w$ diecezji grodzieńskiej [dalej: Szkolnictwo cerkiewno-parafialne $w$ powiecie bielskim $w$ latach...], Białystok 2006, s. 23.

11 И. Корчинский, Очерк истории цеекконо-икольного дела в Гродненской губерни XIX столетии, [в:] Гродненские Eпархиальные Ведомости [dalej: ГЕВ] 1903, нр 21, с. 233.

12 Цит. из: А. Mironowicz, Prawosławne szkolnictwo teologiczne..., s. 874 .

13 Сведения о иерковно-приходских и домашних иколах грамотности действующих в настоящем 1884/1885 учебном году, [в:] Литовские Епархиальные Ведомости [dalej: ЛЕВ] 1885, нр 21, с. 209-210.

14 Ведомость о домашних школах грамоть Литовской епархии за 1886/1887 год, ЛЕВ 1887, нр 44, с. 390-391. 
ский ${ }^{15}$, священник прихода в Пухлах (польск. Puchły), имеющий в этом вопросе огромный опыт.

Перед Первой мировой войной в Бельском повете ${ }^{16}$ умело читать и писать $47 \%$ всего населения ${ }^{17}$. В конце XIX и начале XX в. в. число жителей Клейникского прихода составило 3500 человек и систематически увеличивалось. На его территории в 1905 г. динамично развивались 3 церковно-приходские школы, 1 школа Министерства просвещения и 9 школ грамоты1 ${ }^{18}$. Женские одноклассные школы обычно открывались в относительно крупных населенных пунктах. Одна из таких школ временно функционировала в Клейниках ${ }^{19}$. Но по причине отсутствия финансовой поддержки и пассивной позиции родителей в скором времени была закрыта.

В начале 80-х годов XIX в. на территории Клейникского прихода благодатную почву для своего развития нашло церковное просвещение. Церковно-приходские школы сыграли значительную роль в жизни деревни. Полное возрождение церковно-приходской школы произошло в 1884 г. Тогда царь Александр III утвердил так называемые Правила о церковно-приходских школах. На практике это означало, что приходские школы получили определенный юридический статус и возможность финансирования из государственного бюджета ${ }^{20}$. В октябре 1884 г. во многих селах и деревнях прихода были созданы так называемые иколь грамоты. Это стало возможным благодаря новой школьной политике Святейшего Синода, во главе которого с 1880 г. стоял оберпрокурор К. П. Победоносцев. Он считал, что учреждение школ грамоты и церковно-приходских школ является для государства первостепенной задачей. В письме к царю Александру III он, в частности, писал: ,„...Народ у нас пропадает, раскол и секты держатся от невежества: люди выростают, не получая первых, самых основных понятій о Боге, о Церкви, о заповедях $[\ldots] . . ., 21, ;$,...Для блага народного необходимо, чтобы повсюду близости от него, и именно около приходской церкви первоначальная школа грамотности, в неразрывной связи с ученіем закона Божія и церковнаго пенія $[\ldots] \ldots{ }^{\prime .}{ }^{\prime 22}$. Создание этих школ имело целью, прежде всего, ликвидацию неграмотности и не-

\footnotetext{
15 I. Matus, Powiatowy Oddziat Diecezjalnej Rady Szkolnej w Bielsku w latach 1890-1915-działalność i skład personalny, [w:] Białoruskie Zeszyty Historyczne [dalej: BZH], Białystok 2004, nr 21, s. 71.

16 К Бельскому повету относились три деканата, а именно: Бельский, Дрогичинский и Клещеловский. До конца XIX в. Бельский повет принадлежал Литовской епархии, а после 1900 г. новообразованной Гродненской епархии.

17 Ю. Туронак, Нарыс развіция школьніцтва на Беласточчыне у 1773-1939 2., [у:] Навуковы зборнік, пад рэд. М. Кандрацюка, Беласток 1974, с. 98-99.

18 Справочная Книжка Гродненской Епархии на 1915 год, Гродна 1905, c. 78.

19 Справочная Книжска Гродненской Губернии на 1915 г., с. 176-177.

20 I. Matus, W Puchłach, Stawku, Trześciance. Z dziejów oświaty ludu białoruskiego na Podlasiu, Białystok 2000, s. 21.

21 К. Победоносцев, Письма Победоносцева к Александру III, Петербург 28 марта 1883 г., Москва 1926, Т. II, с. 27-28.

22 И. К. Смолич, История Русской Церкви 1700-1917, Москва 1997, T. VIII, ч. 2, c. 105.
}

вежества в безписьменных деревнях. Их учреждение было обусловлено заявлением о деятельности школы в органы просвещения при посредничестве настоятеля данного прихода. Чаще всего в селах школы открывались самими православными священниками. В то время настоятелем в Клейниках был священник Викентий Кречетович ${ }^{23}$. В начале 1884 г. он был организатором и председателем всех собраний прихожан во всех селах Клейникского прихода. На собраниях принимались решения об учреждении так называемых Домашних крестянских школ или, как их еще называли, школ грамоты. За свою работу в 1895 г. он был награжден орденом Св. Анны, третьей степени ${ }^{24}$. Школы, созданные на территории прихода, сталкивались с проблемами организационного характера и финансовыми. Самым затруднительным был недостаток помещений для ведения уроков. Неоднократно родители детей, посещающих школы, предоставляли свои дома для нужд школы. В 1909-1914 г. г. в Бельском повете было построено только несколько школьных зданий ${ }^{25}$. Родители также обязывались содержать учителей ${ }^{26}$, то есть предоставлять им жилье и питание. Кроме пожертвований родителей, учителя могли обращаться за денежными пособиями. Чаще всего их выдавали на лечение. Пособия назначались Епархиальным училищным советом. Исключение составляли пособия, выплачиваемые из средств Земского Собора. Из этого источника в 1908 г. 60 рублей получила учительница одноклассной церковно-приходской школы в Янове, Ольга Калишевич ${ }^{27}$. В 1907 г. были обеспечены собственные классные помещения для одноклассных школ в Городчине ${ }^{28}$ и Кожине ${ }^{29}$. Не во всех приходских школах учебный год начинался регулярно. Часто начало учебного года откладывалось до завершение всех полевых работ. Обычно учебный год в сельской местности начинался с октября или ноября и заканчивался в марте, когда наступала пора весенних работ. Обучение продолжалось полгода. В зимний период дети имели больше времени на посещение таких школ. Весной и летом дети помогали своим родителям, поскольку составляли некоторый процент рабочей силы в хозяйстве.

\footnotetext{
23 Священник Викентий Кречетович за вклад в развитие церковно-приходского обучения в учебном 1893/1894 г. был удостоен престижной записи в личном деле, так называмых послужных списках, см.: Обявляется признательность Епархиального Начальства со внесением в послужой список каждого, ЛЕВ 1895, нр 19, с. 183. Отец Викентий Кречетович состоял также членом комиссии, которая попечительствовала строительству школы в Трестянке-Ставке.

24 ЛЕВ 1895, c. 192.

25 I. Matus, Szkolnictwo cerkiewno-parafialne w powiecie bielskim $w$ latach...s. 212.

26 Работающие в школе в Козликах учителя зарабатывали примерно по 5 рублей, см.: Российский Государственный Исторический Архив [далее: РГИА] в Санкт-Петербурге, ф. 803, оп. 16, д. 365, Школьные листки, к. 162.

27 Журнал Гродненского Епархиального Училищного Совета, ГЕВ 1908, нр 42, с. 313.

28 РГИА в Санкт-Петербурге, ф. 803, оп. 16, д. 365, Школьные листки, к. 20.

29 Ibidem, л. 117.
} 
Самой большой проблемой и заботой учителей было отсутствие книг и учебных пособий. Учителями часто были абсолютно не подготовленные к этой должности лица, не имеющие ни достаточных знаний, ни педагогических навыков. Исключение составляли Валентина Шишко и Антоний Рушкевич. Валентина Шишко работала в школе в Городчине и имела звание учителя одноклассной церковно-приходской школы. Она была выпускницей женской церковно-учительской школы в Ружаныстоке (польск. Różanystok) ${ }^{30}$. А Антоний Рушкевич ${ }^{31}$, уроженец Нурца (польск. Nurzec) $)^{32}$, окончил второклассную церковно-приходскую школу в Дрогичине (польск. Drohiczyn). В школах преподавал с 1901 года ${ }^{33}$. В основном это были выпускники Народных училищь, то есть образовательных учреждений, находящихся под надзором государства, а иногда и учителя-самоучки. Среди учителей, которые учили в школах грамоты, учрежденных на территории прихода в Клейниках, трое из них из школ в Городчине, Льахах и Градочне окончили Кленикское народное училище, два учителя из школ в Ступниках и Козликах не окончили никакой школы ${ }^{34}$.

В школах грамоты преподавались, прежде всего, чтение и письмо, а также предметы, связанные с религиозным обучением, то есть катехизис, церковное песнопение и основы церковнославянского языка. Школа в Клейниках была одним из образовательных учреждений, которое достигло наилучших результатов и отличилось в обучении религии и церковного песнопения ${ }^{35}$.

В октябре 1884 г. на территории Клейникского прихода было создано восемь школ грамоты. Их развитие в первые годы (1884-1887) функционирования представлено в ниже в перечне ${ }^{36}$.

Городчино (Клейникский приход)-Передвижная школа грамотьл. Открыта в октябре 1884 г. В учебном 1884/85 г. в ней учились 22 мальчика и 7 девочек, в 1885/86-18 мальчиков и 10 девочек, 1886/87-21 мальчиков и 16 девочек. Учителя-священник и крестьянин

\footnotetext{
30 I. Matus, Szkolnictwo cerkiewno-parafialne w powiecie bielskim w latach...s. 171.

31 Рушкевич принадлежал к тем учителям, которые не сторонились местной общественности. Он был музыкально одаренным человеком. Играл на скрипке и прекрасно пел. Длинные зимние вечера проводил с сельской молодежью на пении любимых песен. Таким образом он приобретал симпатию и большое доверие у местных жителей. Вместе разучивали новые песни. В основном это были местные или русские народные песни, см.: I. Matus, Szkolnictwo cerkiewno-parafialne $w$ powiecie bielskim $w$ latach... s. 285.

32 Памятная Книжка Гродненской Губернии на 1905 год, Гродна 1905, c. 115-116.

33 Białoruskie Państwowe Archiwum Historyczne w Grodnie, ф. 23, оп. 2, д. 1467 б, О назначении содержания духовенству и учащим иерковных икол Гродненской епархии за 1913 г., к. 20 б-23 а.

$34 \pi E B, 1885$, c. 209.

35 I. Matus, Szkolnictwo cerkiewno-parafialne w powiecie bielskim pod koniec XIX i na poczatku XX wieku, Białystok 1994, BZH, nr 2, s. 55-56.

36 P. Bajko, Rozkwit cerkiewnego szkolnictwa elementarnego w latach 80. i 90. XIX wieku na terenie obecnego województwa białostockiego, Białystok 1999, BZH, z. 11, s. 87, 88, 91, 93, 100, 103.
}

Кирилл Иванюк, окончивший народную школу в Клейниках ${ }^{37}$.

Градочно (Клейникский приход)-Передвижная школа грамоты. Открыта в октябре 1884 г. В учебном 1884/85 г. в ней учились 18 мальчиков и 5 девочек, в 1885/86-19 мальчиков и 3 девочки, в 1886/87-22 мальчика и 5 девочек. Учителя-священник и крестьянин Корнелиуш Савчук, окончивший народную школу в Клейниках ${ }^{38}$.

Гуковиче (Клейникский приход)-Передвижная школа грамоты. Открыта в октябре 1884 г. В учебном 1884/85 г. в ней учились 17 мальчиков и 6 девочек, в 1885/86-17 мальчиков и 7 девочек, в 1886/87-23 мальчика и 12 девочек. Учителя-священник и отставной обер-офицер Федор Никитюк, учился в полковой школе $\mathrm{e}^{39}$.

Кожино (Клейникский приход)-Передвижная школа грамоты. Открыта в октябре 1884 г. В учебном $1884 / 85$ г. в ней учились 21 мальчиков и 8 девочек, в 1885/86-19 мальчиков и 10 девочек, в 1886/87-23 мальчика и 6 девочек. Учителя-священник и крестьянин Ваилий Игнатюк, окончивший народную школу в Трестянке ${ }^{40}$.

Козлики (Клейникский приход)-Передвижная школа грамотыл. Открыта в октябре 1884 г. В учебном 1884/85 г. в ней учились 14 мальчиков и 8 девочек, в 1885/86-13 мальчиков и 11 девочек, в 1886/87-12 мальчиков и 21 девочка. Учителя-священник и крестьянин Петр Оверчук, окончивший народную школу ${ }^{41}$.

Льахи (Клейникский приход)-Передвижная школа грамоты. Открыта в октябре 1884 г. В учебном 1884/85 г. в ней учились 19 мальчиков и 6 девочек, в 1885/86-17 мальчиков и 13 девочек, в 1886/87-18 мальчиков и 14 девочек. Учителя-священник и крестьянин Лука Комасов, окончивший народную школу в Клейниках ${ }^{42}$.

Ступники (Клейникский приход)-Передвижная школа грамоты. Открыта в октябре 1884 г. В учебном 1884/85 г. в ней учились 14 мальчиков и 8 девочек, в 1885/86-19 мальчиков и 8 девочек, в 1886/87-14 мальчиков и 8 девочек. Учителя-священник и крестьянин Антоний Карчевский, окончил вначале домашнюю школу, а затем народную школу ${ }^{43}$.

Яново (Клейникский приход)-Передвижная школа грамоты. Открыта в октябре 1884 г. В учебном 1886/87 г. в ней учились 10 мальчиков и 10 девочек, в 1906 г.-9 мальчиков и 7 девочек ${ }^{44}$.

Как вытекает из годовых отчетов, в учебном 18841885 г. на территории прихода такие школы существовали в селах: Гуковиче, Кожино, Ступники, Козлики, Льахи, Яново, Градочно и Городчино ${ }^{45}$.

\footnotetext{
37 ЛЕВ 1886 , нр 43, с. 428; 1887 , нр 44, с. 390.

38 ЛЕВ 1885, нр 21, с. 209; 1886, нр 43, с. 428; 1887, нр 44, с. 391.

39 ЛЕВ 1885, нр 21, с. 209; 1886, нр 43, с. 428; 1887, нр 44, с. 390.

$40 \quad J E B 1885$, нр 21, с. $209 ; 1886$, нр 43, с. 428; 1887, нр 44, с. 390.

${ }_{41}$ ЛЕB 1885, нр 21, с. 209; 1886, нр 43, с. 428; 1887, нр 44, с. 390.

42 ЛЕВ 1885, нр 21, с. 209; 1886, нр 43, с. 428; 1887, нр 44, с. 390.

43 ЛЕВ 1886 , нр 43, с. 428; 1887, нр 44, с. 390.

44 ЛЕВ 1887, нр 44, с. 390; BZH 1997, нр 7, с. 134.

45 ЛЕВ 1885 , с. $209 ; 1886$, с. $428 ; 1887$, с. 390.
} 
В 1890 г. в приходе была открыта очередная школа грамоты в местности Тиневичи (польск. Tyniewicze). Общее число посещающих 9 церковных школ на территоории прихода составил более 250 детей ${ }^{46}$.

В 1892 г. в печатном органе Литовской епархии была напечатан материал, посвященный цколам грамоты в Клейникском приходе ${ }^{47}$. В следующем году в центральном издательстве Православной Церкви появилась статья: О школах грамоты и ичерковном пении в Кленикском приходе $e^{48}$. Ее автор высоко оценил понимание родителей и усилия детей в получении знаний, одновременно подчеркивая, что на распространении народного просвещения много выиграл также и сам приход, получив три церковных хора, которые своим пением украшали праздничные и повседневные богослужения.

К концу XIX в. из 13 сел, входящих в состав Клейникского прихода, в 11 существовали школь грамоты, в которых обучались грамоте 240 детей. Школь грамоmы, как и Народное училище сильно помогли поднять уровень просвещения среди постоянно увеличивающегося числа детей и молодежи в Клейникском приходе. В 1891 г. общая численность прихожан составила 3529 человек, проживающих в 440 домах ${ }^{49}$. В 1893/1894 г. г. шесть мальчиков из Клейникского прихода окончили церковно-учительскую школу в Трестянке-Ставке (польск. Trześcianka-Stawek) ${ }^{50}$. Список этих мальчиков вместе с остальными выпускниками был опубликован на страницах прессы ${ }^{51}$. Выпускниками упомянутой школы были: Марк Иванюк, сын Василия, село Радьки (польск. Radźki) Бельского повета; Петр Мартынюк, сын Иоана, село Козлики Бельского повета; Василий Калиновский, сын Максима, село Клейники Бельского повета; Калистрат Томашук, сын Василия, село Яново Бельского повета; Теофан Томашук сын Иоана, село Яново Бельского повета; Иоанн Яконюк, сын Игнатия, село Кожино Бельского повета.

В 1896 г. еще два мальчика окончили церковно-учительскую школу в Трестянке-Ставке, получив таким образом звание учителя одноклассной церковно-приходской школы ${ }^{52}$. Выпускниками школы в упомянутом году были: Поликарп Василюк, сын Теодора, село Яново Бельского повета; Ананий Гаврилюк, сын Николая, село Клейники Бельского повета ${ }^{53}$.

Значимую роль в организации жизни в селе Клейники в то время сыграл настоятель прихода священник

\footnotetext{
46 Епископ Иосиф (Соколов) [далее: Иосиф (Соколов)...], [в:] Гродненский православно-церковный календарь или православное обозрениие в Брестско-гродненской земле в коние XIX в., Воронеж 1899, T. I, c. 364 .

47 ЛЕВ 1892, с. 358.

48 Прибавления к Церковнылм Ведомостям, Санкт-Петербург 1893, нр 43, с. 1778-1779.

49 G. Sosna, Klejniki, [w:] Wiadomości Polskiego Autokefalicznego Kościoła Prawosławnego, Warszawa 1987, nr 1, s. 64-65.

50 I. Matus, Szkolnictwo cerkiewno-parafialne $w$ powiecie bielskim w latach...s. 55

51 Объявленние от Кирилло-Мефодиевской церковно-учительской школь в с. Ставке Бельского уезда, ЛЕВ 1894, нр 26, с. 226-227.

52 I. Matus, W Puchtach..., s. 59-60.

53 Местные известия. „Список”, ЛЕВ 1896, нр 28, с. 290.
}

Иоанн Хлебцевич. Он родился в 1857 г. в Седельниках близ Волковыска, Гродненской губернии в семье псаломщика. В Клейники прибыл из Жировиц, посвящение в духовный сан принял в возрасте 40 лет. В 1897 г. получил свой первый приход, которым были Клейники ${ }^{54}$. Его более чем десятилетнее пребывание в Клейниках характеризовалось интенсивной пастырской и общественной деятельностью, а также огромным вкладом в развитие церковно-приходского обучения среди населения близлежащих сел и деревень. Местная, прежде всего, белорусская интеллигенция считала его просвещенным человеком и большим авторитетом.

Он воспитал своих двух сыновей в духе толерантности и привязанности к национальным белорусским традициям. Один из них, Евгений, подписывающий свои статьи псевдонимом Халімон с-пад Пушчь, был постоянным корреспондентом белорусской газеты Наша Ніва (общественно-культурный и литературный еженедельник, выходил в Вильнюсе на белорусском языке). Второй сын, Влодимир был автором набросков о селе Клейники перед I Мировой войной, которые хранятся в Национальной Библиотеке Беларуси, а опубликованы были в Белорусском историческом журнале ${ }^{55}$. Священнослужитель Иоанн Хлебцевич своей позицией снискал уважение и долгую память местного населения. За образцовую работу в пользу церковно-приходского обучения в 1909 г. епископ наградил священника Иоана Хлебцевича, руководящего обучением в приходской школе ${ }^{56} c \kappa y ф ь е u^{57}$.

Как следует из описания Влодимира Хлебцевича, село Клейники перед I Мировой войной насчитывало 1200-1500 жителей в 200 домах $^{58}$. В селе также проживали 3 еврейские семьи и несколько семей сельской интеллигенции. Жители были очень работящие. Основным занятием местного населения было сельское хозяйство, ремеслом занимались только несколько человек. Причиной низкой производительности была почва очень низкого класса, а также низкий уровень аграрной культуры среди крестьян. Отец Иоанн Хлебцевич обращал особое внимание на повышение уровня сельского хозяйства на территории прихода. Он поощрял посещение сельской библиотеки крестьянами и чтение книг и журналов, посвященных современным методам хозяйствования ${ }^{59}$.

\footnotetext{
54 Я. Хлябцэвіч, Біяграфія баџькі, Białystok 1996, BZH, nr 1 (5), s. $118-119$.

55 В. Хлебцевич, Село Кленики перед беженством-во время мировой войны [dalej: Село Кленики...], Białystok 1995, ВZH, nr 2 (4), s. $132-145$.

56 Епархиальные распоряжения и извешения, ГЕВ, Гродна 1905, нр 19, с. 530.

57 Скуфья-повседневный головной убор православного духовенства в виде мягкой шпочки черного (фиолетового) иявета см.: H. Fediukina, Leksykon terminologii prawosławnej rosyjsko-polski. Z cytatami tekstów biblijnych, Warszawa 2014, Warszawska Metropolia Prawosławna, s. 221

58 Там же, с. 142.

59 И. Хлебцевич, Несколько слов по аграрному вопросу, ГЕВ, Гродна 1909 , с. $345-360$.
} 
Отец Иоанн Хлебцевич был одним из немногочисленных священнослужителей, которые активно поддерживали создание библиотек им. Павленкова. Выдающимся событием в жизни прихода стало открытие такой библиотеки-читальни в Клейниках в 1907 г. Так о своей библиотеке писал отец Иоанн в своих воспоминаниях: „,...) Большую часть дня и длинные вечера я посвящал книгамъ, книгамъ и книгамъ. У меня была очень порядочная библіотека со множествомъ илюстрированныхъ журналовъ за разные годы, массою брошюръ и дътскихъ книгъ”. Она функционировала на протяжении нескольких лет, а учредил ее лично отец Иоанн. Библиотекарем был житель села Василий Федорук, в доме которого она располагалась ${ }^{60}$. Иоанн Хлебцевич интересовался историей Беларуси и переписывался с Иоаном Луцкевичем, который был известен не не только как белорусский политический деятель, но и как большой любитель древности ${ }^{61}$. При организации библиотеки отцу Иоану помогал его сын Евгений. В 1909 г. он организовал в селе Клейники театральный кружок, который при неимении белорусского репертуара подготовил украинскую комедию Разумны і дурань, автор Тубилевич (Карпенко-Карий). О роли упомянутой в переписке Е. Хлебцевича сельской библиотеки в клейникском обществе можем прочитать в другой переписке, также опубликованной в газете Наша Ніва (номер 28-29/1909 г.). Вот что пишет автор, которая подписалась как Женщина Наталка: ,, ...сколько пользы приносят нашим крестьянам библиотеки-книгохранилища, отличный пример можем видеть и узнать и в нашем селе. Совсем недавно здесь было создано такое книгохранилище, а люди стали уже лучше, спокойнее, [...]. Крестьяне начали осознавать и уважать свое человеческое достоинство, понимать, что они такие же самые люди как и все другие. Уже не дрожат перед своим начальством так, как прежде, потому что читают книги, хорошо знают, что можно, а чего нельзя. Книги берут не только мужчины, но и женшины грызут их как репку; сейчас даже ругани между ними слышны меньше, чем раньше; а что касается детей, то их нельзя даже оторвать от чтения. Можно с уверенностью ожидать, что если так будет и дальще, то наши крестьяне станут культурными, разумными людьми ${ }^{62}$. Доход от представления был предназначен на библиотеку-читальню. Евгений Хлебцевич был также инициатором открытия в Клейниках кооперативного магазина.

Созданная библиотека была призвана приобщить крестьян к чтению и сломить их пассивный подход к попыткам внедрения прогресса в сельской местно-

\footnotetext{
60 М. Базылюк, Жыциё і дзейнасць Яуггена Хлябцэвіча на фоне „Нашай Нівы”, Магістарская дысертацыя напісаная пад кірункам доктара А. Баршчэўскага, Кафедра Беларускай Філалогіi, Варшава 1986, c. 11.

${ }_{61}$ P. Chomik, H. Głogowska, S. Iwaniuk, O. Łatyszonek, E. Mironowicz, Z. Misiuk, H. Siemianczuk, Historia Białorusinów Podlasia, Białystok 2016, Białoruskie Towarzystwo Historyczne, s. 201-202.

62 J. Hawryluk, Ukraiński teatr we wsi Kleniki, [w:] Над Бугом і Нарвою, Bielsk Podlaski 1993, nr 1, s. 16.
}

сти. Не все жители оценили письменную культуру и понимали потребность создания библиотеки. Начало деятельности библиотеки требовало соблюдения определенных формальностей. Разрешение на ее открытие выдавал губернатор, а для получения согласия необходимо было подать прошение с указанием источника финансового обеспечения и предоставления помещения. Попытка открыть в Клейниках библиотеку-читальню была сделана еще до 1907 г. В селе было проведено собрание, на котором более сознательная часть крестьян приняла решение о передаче на содержание библиотеки 20 рублей. Однако до реализации задуманных целей не дошло. Некоторые жители не понимали потребности ее создания, их позиция была пассивной, а иногда даже враждебной. В конце концов библиотека была открыта летом 1907 г. $^{63}$. Из фонда Павленкова ${ }^{64}$ на нее было выделено 150 рублей ${ }^{65}$. За полученные деньги были куплены книги. В 1909 г., кроме собственных произведений, много книг из частного собрания в библиотеку в Клейниках передал великий русский писатель Лев Толстой ${ }^{66}$. Он вел активную переписку не только с отцом Хлебцевичем, но и с некоторыми жителями села Клейники. В начале существования библиотека насчитывала около 500 томов стоимостью 600-800 рублей.

Зимой 1908 г. библиотека-читальня столкнулась с первыми финансовыми проблемами. Нужны были деньги на покупку новых книг и переплет уже имевшихся экземпляров. Небольшая группа крестьян, в большинстве своем с не очень хорошей репутацией, сильно пьющих, начала острую кампанию против библиотеки и ее финансирования. Под их влиянием сельчане отказались от финансирования библиотеки. Враждебно настроенную группу и ее сторонников удалось победить резкими словами критики на страницах газеты Наша Ніва, автором которых был Халімон c-nад Пушчы: „...W. Kleniki. Bielskaho paw. Hrodzien. hub. 12 studnia byŭ tut sielski schod ab bibljotecyczytalni imieni Pawlenkowa. Schod szoŭ tak, szto styd i soram za jaho ŭsim mužykam tutejszym! I chto moh by pawieryć, szto hramada statych ludziej pastuchaje adnaho pjanoha mužyka?-A heta i zrabilosia na schodzi, katory stuchaŭvniejakoho pjanuhi, szto dawodziŭ: ,na szto nam bibljoteka; lepsz kuplu za piać złotych psattyr, dyk budzie $\breve{u}$ mianie nazaŭsiahdy!” Bibljoteka-czytalnia ledźwie tolki paczata szyryć wakruh swoj jasny świet, siejaci ziernie dabra, praŭdy i nawuki; i woś užo ludzi paczynajuć taptać hetu wialikuju rabotu. Wychodzić szto hutarka pjaniuhi

\footnotetext{
63 В. Хлебцевич, Село Кленики..., с. 139.

64 Фонд Павленкова был создан на средства книгоиздателя Ф. Павленкова. Он жил в 1839-1900 г. г. Издал более 750 книг. За распространение революционных идей он подвергался преследованиям царского правительства и был сужден на 10 лет тюрьмы. Доходы от издательской деятельности он завещал на устройство 2 тыс. сельских библиотек, см.: I. Matus, Biblioteki-czytelnie im. Florentego Pawlenkowa $i$ towarzystwa kredytowe $w$ białoruskich wsiach Podlasia na poczatku XX wieku, Białystok 1994, BZH, nr 1, s. 10.

65 В. Хлебцевич, Село Кленики..., с. 141.

66 Там же, c. 141.
} 
naszym mužykom z Klebanoŭ i Zahacia darażaj za dzietak, katoryje biaruć z bibljoteki knižki. Zrazumiejcie, ludcy, szto bibljoteka budzie dla was karystna, kali jaje budziecie padtrymywać. Ciapier usiaho 500 knižok, a treba da ich parabić akładki, kab nie rastraslisia, nie parwalisia. Woś že i sam niaboszczyk Pawlenkoŭ pakinuŭ pa śmierci üsio dabro $i$ knižki swaje, kab dawać pomacz narodnym bibljotekam, ale s tym warunkam, kab i sami mužyki sawali krychu hroszej na utrymańnie bibljotek. Pawlenkoŭ daje kniei bolsz jak na 100 rub., kali daduć na bibljoteku 50 rub. samy mužyki. Chalimon s-pad puszczy"67. Жители села солидарно приняли решение содержать библиотеку. Каждая семья обязалась предназначить по несколько копеек на переплетение имеющегося собрания книг ${ }^{68}$. Несмотря на это, группа упрямых крестьян не прекратила враждебную кампанию против читальни. Они написали донос губернатору, в котором обвиняли библиотеку в хранении нелегальной литературы. В 1908 г., по поручению губернатора в Клейникской библиотеке была проведена ревизия. Ничего запрещенного цензурой найдено не было, только было приказано изъять из собрания библиотеки книги известных русских поэтов, Федора Достоевского и Льва Толстого. Было указано, что они не предназначены для такого рода библиотек. Священнику и библиотекарю пригрозили денежным штрафом, если они не выполнят поконтрольные указания.

Библиотека в Клейниках просуществовала до 1915 г. Из рассказа Влодимира Хлебцевича следует, что перед вступлением в село немецкого войска и отъездом семьи Хлебцевичей вглубь России книги были спрятаны в церкви под ризницей. Спрятанные там книги сгорели во время пожара церкви в 1973 г. Очень ценное собрание книг и важные документы были утрачены навсегда. Уже после пожара церкви были открыты обгоревшие книги, земские документы, королевские указы и другие приходские документы. Среди найденных документов также была приходская хроника со старой

${ }^{67}$ См.: Наша Ніва, 1908, нр 3, с. 6.

68 I. Matus, Biblioteki-czytelnie..., s. 13. церковной летописью. Прихожане, не отдавая себе до конца отчет в ценности находки, все обгоревшие документы сожгли на пепелище церкви. Таким образом они как бы безвозвратно уничтожили часть истории своей местности и прихода ${ }^{69}$. В письме от 25 сентября 1915 г. Влодимир писал своему брату Евгению: ,,...усе сёльг гарэлі пры непрысутнасці нашых людзей. Кнігі (10 скрыняу) закапаны у вельмі надзейным месиьы. Там тваё усё...”. Упомянутые в письме закопанные ящики много лет искала учительница белорусского языка и литературы Мария Базылюк. К сожалению, безвозвратно утраченные книги отыскать не удалось.

В начале XX в. жители села Клейники жили не только библиотечными делами. Они занимались также возделыванием земли и другими работами, которые давали им удовлетворение и возможность содержания своих семей. Один из жителей, Михаил Карпинский ${ }^{70}$, занимался пчеловодством и торговлей лошадьми. Это был уважаемый в селе человек. Он сам причислял себя к сельской интеллигенции. Его дом находился в центре села, на диалекте Клебанщине, и выделялся среди крестьянских хат. Влодимир Хлебцевич так его описывал в своих дневниках: „...был небольшой, беленый дом, очень ухоженный снаружи и уютно обустроенный внутри..." ${ }^{\prime 71}$.

Если говорить в общем, то ситуация церковно-приходского обучения в Клейникском приходе не было на специально высоком уровне. Но сыграла существенную роль в повышении уровня просвещения и в значительной степени помогла в борьбе с неграмотностью, неумением читать и писать и с отсталостью клейникский прихожан того времени.

${ }^{69}$ A. Kuprianowicz, Z dziejów parafii prawosławnej w Klejnikach. Okres II wojny światowej oraz lata powojenne, [w:] Bielski Hostineć, Bielsk Podlaski 2016, nr 2 (54), s. 84.

70 Михаил Карпинский был потомком интеллигентского рода Карпинских из села Клейники. Потомки рода Карпинских в настоящее время проживают в России и в Польше, см.: 3. Ждан, Карпінскія з Кленік, [w:] Bielski Hostineć, Bielsk Podlaski 2015, nr 2 (52), s. 3-11.

71 В. Хлебцевич, Село Кленики..., с. 139.

\section{Литература}

Bajko P., Rozkwit cerkiewnego szkolnictwa elementarnego w latach 80. i 90. XIX wieku na terenie obecnego województwa białostockiego, [w:] Białoruskie Zeszyty Historyczne, Białystok 1999, z. 11.

Базылюк М., Жыциё і дзейнасиь Яўгена Хлябиэвіча на фоне „Нашай Нівы”, Магістарская дысертацыя напісаная пад кірункам доктара А. Баршчэўскага, Кафедра Беларускай Філалогіi, Варшава 1986.

Białoruskie Państwowe Archiwum Historyczne w Grodnie, ф. 23, оп. 2, д. 1467 б, О назначении содержания духовенству и учащиим иерковных школ Гродненской епархии за 1913 г., к. 20 б-23 а.
Хлебцевич В., Село Кленики перед беженством-во время мировой войнь, [в:] Białoruskie Zeszyty Historyczne, Białystok 1995, nr 2 (4).

Хлебцевич И., Несколько слов по аграрному вопросу, [в:] Гродненские Епархиальные Ведомости, Гродна 1909.

Хлябцэвіч Я., Біяграфія баџькі, [у:] Biatoruskie Zeszyty Historyczne, Białystok 1996, nr 1 (5).

Chomik P., Głogowska H., Iwaniuk S., Łatyszonek O., Mironowicz E., Misiuk Z., Siemianczuk H., Historia Białorusinów Podlasia, Białystok 2016, Białoruskie Towarzystwo Historyczne.

Fediukina H., Leksykon terminologii prawosławnej rosyjsko- 
polski. Z cytatami tekstów biblijnych, Warszawa 2014, Warszawska Metropolia Prawosławna.

Hawryluk J., Ukraiński teatr we wsi Kleniki, [w:] Над Бугом i Нарвою, Bielsk Podlaski 1993, nr 1.

Епархиальные распоряжения и извешения, [в:] Гродненские Епархиальные Ведомости, Гродна 1905, нр 19.

Епископ Иосиф (Соколов) [в:] Гродненский православно-иерковный календарь или православное обозрениие в Брестско-гродненской земле в конце XIX в., Воронеж 1899, Т. I.

Корчинский И., Очерк истории иерковно-икольного дела $в$ Гродненской губерни ХІХ столетии, [в:] Гродненские Епархиальные Ведомости 1903.

Kuprianowicz A., Z dziejów parafii prawosławnej w Klejnikach. Okres II wojny światowej oraz lata powojenne, [w:] Bielski Hostineć, Bielsk Podlaski 2016, nr 2 (54).

Литовские Епархиальные Ведомости, 1885, 1886, 1887, 1892, 1895.

Matus I., Biblioteki-czytelnie im. Florentego Pawlenkowa i towarzystwa kredytowe $w$ białoruskich wsiach Podlasia na poczatku XX wieku, [w:] Białoruskie Zeszyty Historyczne Białystok 1994, nr 1.

Matus I., Kursy nauczycielskie. Z historii oświaty cerkiewno-parafialnej w diecezji grodzieńskiej 1900-1915, [у:] Культура Гродзенскага рэгіёну: праблемь развіщия ва ўмовах поліэтнічнага сумежжа. Зборнік навуковых праи, Гродна 2001.

Matus I., Powiatowy Oddziat Diecezjalnej Rady Szkolnej w Bielsku w latach 1890-1915-działalność i skład personalny, [w:] Białoruskie Zeszyty Historyczne, Białystok 2004.

Matus I., Szkolnictwo cerkiewno-parafialne w powiecie bielskim pod koniec XIX i na poczatku XX wieku, [w:] Białoruskie Zeszyty Historyczne Białystok 1994, nr 2.

Matus I., Szkolnictwo cerkiewno-parafialne w powiecie bielskim $w$ latach 1884-1914 na tle sytuacji oświatowej $w$ diecezji grodzieńskiej, Białystok 2006.

Matus I., W Puchłach, Stawku, Trześciance. Z dziejów oświaty ludu białoruskiego na Podlasiu, Białystok 2000.

Mironowicz A., Prawostawne szkolnictwo teologiczne na terenie Rzeczypospolitej, [w:] Od Kijowa do Rzymu. Z dziejów stosunków Rzeczypospolitej ze Stolica Apostolska i Ukraina, red. M. R. Drozdowski, W. Walczak, K. Wiszowata-Walczak, Białystok 2012.

Местные известия. „Список”, [в:] Литовские Епархиальные Ведомости 1896, нр 28.

Нама Ніва 1908, нр 3.

Объявленние от Кирилло-Мефодиевской иерковно-учительской школь в с. Ставке Бельского уезда, [в:] Литовские Епархиальные Ведомости 1894, нр 26.

Обявляется признательность Епархиального Начальства со внесением в послужой список каждого, [в:] Литовские Епархиальные Ведомости 1895, нр 19.

Памятная Книжка Гродненской Губернии на 1905 год, Гродна 1905.

Победоносцев К., Письма Победоносиева к Александру III, Петербург 28 марта 1883 г., Москва 1926, Т. II.

Прибавления к Церковным Ведомостям, Санкт-Петербург 1893, нр 43.

Российский Государственный Исторический Архив в СанктПетербурге, ф. 803, оп. 16, д. 365, Школьные листки, к. 162 , к. 20.

Сведения о иеекквно-приходских и домашних школах грамотности действующих в настоящем 1884/1885 учебном году, [в:] Литовские Епархиальные Ведомости 1885.

Смолич И. К., История Русской Церкви 1700-1917, Москва 1997, T. VIII, ч. 2.

Sosna G., Klejniki, [w:] Wiadomości Polskiego Autokefalicznego Kościoła Prawosławnego, Warszawa 1987, nr 1.

Справочная Книжска Гродненской Губернии на 1915 г., Гродна 1915.

Справочная Книжка Гродненской Епархии на 1915 год, Гродна 1915.

Туронак Ю., Нарыс развічичя школьніитвва на Беласточчыне y 1773-1939 г., [у:] Навуковы зборнік, пад рэд. М. Кандрацюка, Беласток 1974.

Ведомость о домашних школах грамоть Литовской епархии за 1886/1887 год, [в:] Литовские Епархиальные Ведомости 1887, нр 44.

Журнал Гродненского Епархиального Училищного Совета, [в:] Гродненские Епархиальные Ведомости 1908, нр 42.

Rozmiar artykułu: 0,85 arkusza wydawniczego 


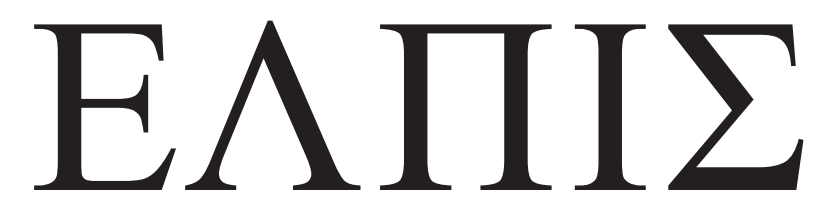

CZASOPISMO TEOLOGICZNE KATEDRY TEOLOGII PRAWOSŁAWNEJ UNIWERSYTETU W BIAŁYMSTOKU

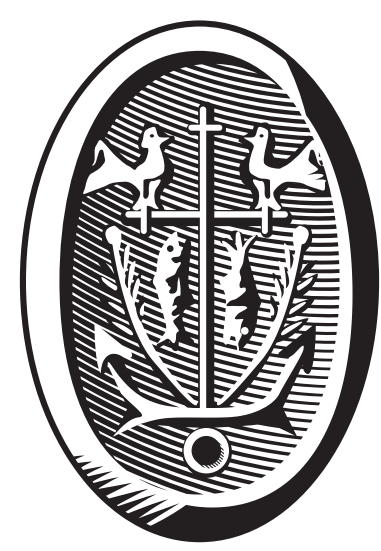

ADRES REDAKCJI

ul. Ludwika Zamenhofa 15, 15-435 Białystok, Polska tel. 85 745-77-80, e-mail: elpis@uwb.edu.pl www.elpis.uwb.edu.pl 